\title{
Oil palm genetic improvement and sustainable development
}

Benoît COCHARD

Philippe AMBLARD

Tristan DURAND-GASSELIN

CIRAD, Département des cultures pérennes, TA 80/03, Avenue Agropolis,

34398 Montpellier Cedex 5, France

\begin{abstract}
Genetic improvement of the oil palm may have a role to play in the sustainability of this crop. Given the criticism aimed at this commodity chain, notably due to the extension of oil palm plantations to the detriment of forests, providing very high-yielding planting material might be a solution, particularly as world demand is continually increasing. This crop is mostly managed by agroindustrialists, but the smallholder sector is developing. It happens that this sector is classed as a sustainable type of agriculture by numerous NGOs, which are also asking plant breeders to take the specificities of smallholdings into consideration.

Oil palm genetic improvement takes numerous criteria into account, many of which fit in with sustainable agriculture. For example, this crop is subject to pressure from different pests and diseases. In each case, a genetic hence eco-friendly approach has been taken and, in particular, vascular wilttolerant planting material has been a successfully produced. Moreover, for the future of this crop, planting material needs to be developed that requires fewer inputs, and consideration has to be given to extending this crop in less favourable zones, by developing planting material that consumes less water. Lastly, it is important to disseminate genetically diversified planting material.
\end{abstract}

Key words: Elaeis guineensis, genetic improvement, sustainable development

in its breeding strategies. If we refer to the Leipzig declaration, increasing yields must remain a very important criterion for genetic improvement. Oil palm genetic improvement has endeavoured to make optimum use of available genetic diversity in its variety creation programmes, notably by working on introducing new populations into the improved planting material, and on a related species, Elaeis oleifera (HBK) Cortes. IPM strategies are being developed against the main pests and diseases of the oil palm, be they of a known nature such as Fusarium oxysporum sp elaeidis and Ganoderma, by using sustainable genetic resistances, or of unknown nature such as bud rot. New "varieties" are being produced and care is being taken to disseminate mixtures of "varieties".

\section{Importance of yield improvement}

Following the devastating fires in Indonesia and Malaysia in 1997, many NGOs severely criticized oil palm cultivation, pointing to it as one of the main causes of primary forest destruction in those countries. It is true that the expansion of oil palm areas in the 1990s often took place in forest zones, thereby appearing to threaten the biodiversity of the ecosystems, and giving rise to numerous disputes with local communities.

World demand for fats and oils is continually increasing, and one rapid way of satisfying that demand is to extend the areas planted to oil crops (table 1). Oil palm growing gives by far the best oil production per unit area planted (table 2). If current trends are confirmed, and there is nothing to indicate that things are going to change, the oil palm commodity chain will have to continue its efforts in order to meet world demand through the sustainably intensified production.

Breeding and genetic improvement work for the crop began in the 1920s in Africa and Southeast Asia. To date, the African populations have undergone two to three generations of improvement. Those in Southeast Asia generally have four to five generations, taking into account the generations of multiplication from agriculture [1]. The long-term objective is reduce genetic erosion and any genetic vulnerability by diversifying agricultural production and increasing the genetic diversity of cultivated plants, whilst keeping in mind the need to increase productivity.

Cultivation of the oil palm, Elaeis guineensis Jacq., is regularly criticized for its environmental aggressiveness (destruction of primary forests, water pollution, etc.). Yet this crop already integrates numerous criteria associated with sustainable agriculture. Apart from agronomic aspects [2], oil palm genetic improvement has long taken into account this concept

Table 1. Changes in cultivated area for the main oil crops (in hectares $x$ 1000). Source Oil World.

\begin{tabular}{|lcccc|}
\hline & 1990 & 1995 & 2000 & 2003 \\
\hline Oil palm & 3560 & 4690 & 6560 & 7950 \\
Soybean & 54910 & 61960 & 75260 & 88800 \\
Sunflower & 16200 & 20230 & 19740 & 22500 \\
Rapeseed & 17790 & 24520 & 25260 & 25620 \\
Cotton & 33920 & 35150 & 32210 & 32240 \\
Groundnut & 19910 & 20590 & 22560 & 22190 \\
Coconut & 8940 & 9210 & 9570 & 9410 \\
\hline
\end{tabular}


Table 2. Production and yield trends for the main oil crops. Source Oil World.

\begin{tabular}{|c|c|c|c|c|c|c|c|c|}
\hline & \multicolumn{4}{|c|}{ Oil production (Tonnes $\times 1000$ ) } & \multicolumn{4}{|c|}{ Oil yields (Tonnes/ha) } \\
\hline & 1990 & 1995 & 2000 & 2003 & 1990 & 1995 & 2000 & 2003 \\
\hline Palm oil & 10710 & 15201 & 21861 & 27920 & 3.01 & 3.24 & 3.33 & 3.51 \\
\hline Soybean & 15760 & 20231 & 25562 & 31284 & 0.29 & 0.33 & 0.34 & 0.35 \\
\hline Sunflower & 7900 & 8635 & 9743 & 8915 & 0.49 & 0.43 & 0.49 & 0.40 \\
\hline Rapeseed & 8720 & 10631 & 14500 & 12548 & 0.49 & 0.43 & 0.57 & 0.49 \\
\hline Cotton & 3860 & 3875 & 2850 & 3964 & 0.11 & 0.11 & 0.12 & 0.12 \\
\hline Groundnut & 3800 & 4252 & 4539 & 4526 & 0.19 & 0.21 & 0.20 & 0.20 \\
\hline Coconut & 8940 & 9210 & 9570 & 9410 & 0.34 & 0.31 & 0.34 & 0.35 \\
\hline
\end{tabular}

individuals introduced in the Bogor Botanical Garden (Indonesia) in 1848 [3]. After a period of slow progress that soon levelled off, linked to mass selection, considerable progress of around $30 \%$ was achieved with the discovery of shell thickness heredity [4]. Thereafter, in the 1950 s, a further $10 \%$ was gained by exploiting heterosis in the crosses carried out between the populations created in Asia and in Africa [5]. In the 1960s, researchers launched a reciprocal recurrent selection scheme at the African stations. The first selection cycle led to a $15 \%$ increase in yields [6], then a second cycle in turn provided progress of a further $15 \%[7,8]$. For example, in a Malaysian company with favourable conditions, oil yields increased from 1.3 tonnes of oil per hectare in 1950 to 5.4 in 1990 , but apparently only half the progress was due to selection [9]. Under less suitable conditions in Ivory Coast, the planting material marketed had a yield potential of 2.9 tonnes of oil/hectare/year in 1950. In 1998, yield potential was 4.1 [10].

All this work, undertaken over the last 50 years, has led to ongoing genetic progress estimated at $1 \%$ per year $[11,7,10]$. Future yields expected under the most suitable conditions ought to reach or exceed 10 tonnes of oil/hectare/year quite rapidly $[3,12]$.

The genetic progress achieved on research stations by breeders needs to be passed on to farmers, who need access to quality planting material [10]. Unfortunately, in too many places, particularly in Africa, smallholdings are planted with so-called "unselected"1 material, for which yields are $60 \%$ lower than those of improved planting materials [13]. If improved planting material is to be distributed to farmers, plant breeders need sufficient seed production capacity. Moreover, the distribution system for improved planting material needs to be developed along the same lines as the nursery network set up in Benin $[14,15]$.

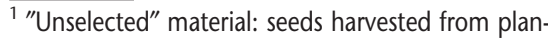
tations.
}

\section{Utilization of genetic resources}

\section{Strengthening genetic diversity}

In the first half of the 20th century, breeders provided growers with selected materials derived primarily from local populations, but little progress had been achieved from those populations, which is why an offer was made to several research institutes to exchange planting materials, which led to the International Experiment [5]. The exchange involved 4 African stations in Ivory Coast, Benin, and the two Congos, along with a station located in Malaysia. The Sabah Department of Agriculture (Malaysia) also organized some exchanges, involving materials from Cameroon and Nigeria. Numerous exchanges took place between stations in the 1970s and 80s, between Benin, Ivory Coast and Nigeria. A joint breeding programme was set up by the Unilever and Harri- sons \& Crosfield groups, which enabled a major exchange of materials between several countries (Cameroon, Colombia, Indonesia, Malaysia, Papua New Guinea, Thailand and the Democratic Republic of Congo) [16]. Since the 1990s, planting material exchanges have been more intermittent, such as between IOPRI ${ }^{2}$ in Indonesia, Ivory Coast and Benin in 1991. To all intents and purposes, current exchange protocols limit genetic mixing, thereby limiting the diversity in the different breeding programmes. We are therefore seeing a degree of contradiction between the decisions taken at the Rio summit in 1992 which, due to the use made by countries, has led to a virtual halt in exchanges, and the determination expressed in the Leipzig declaration in 1996 to promote the diversity of the plants and the varieties used.

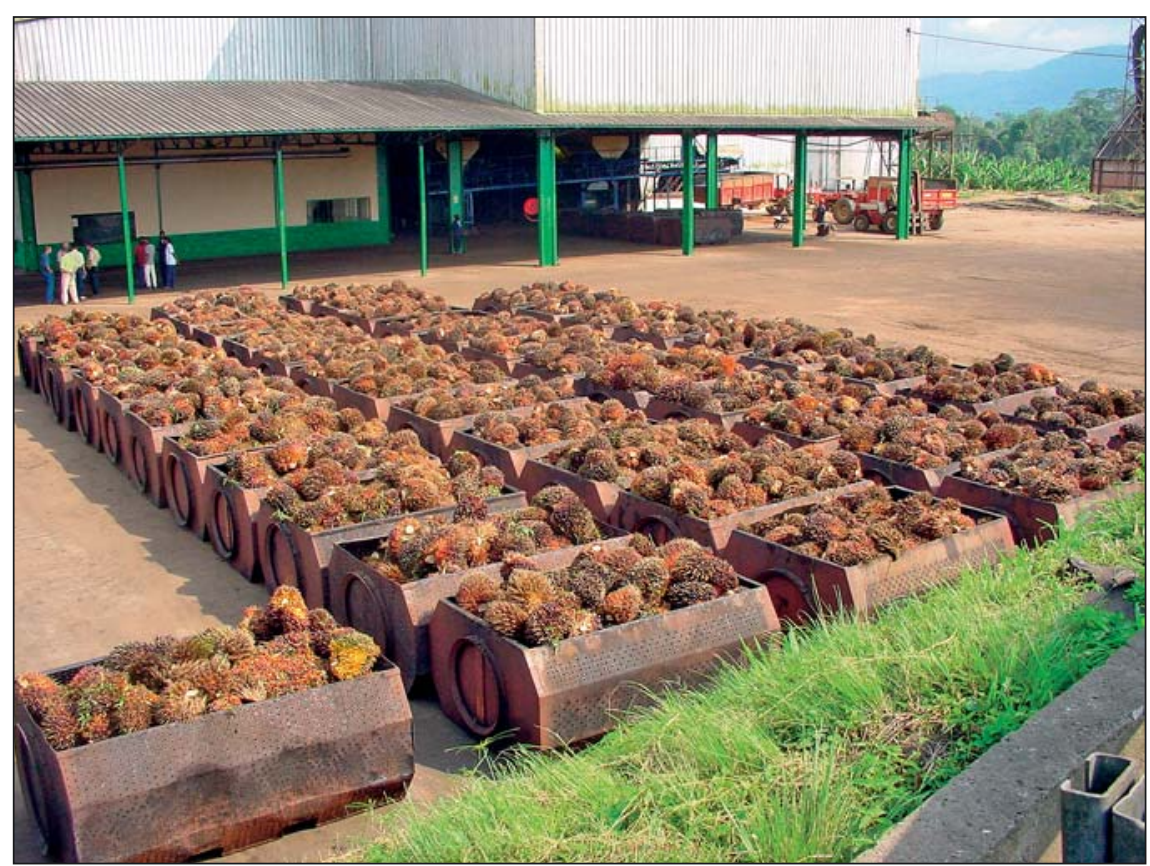

Figure 1. The aim of oil palm breeding is to secure production (Photo : T. Durand-Gasselin). 


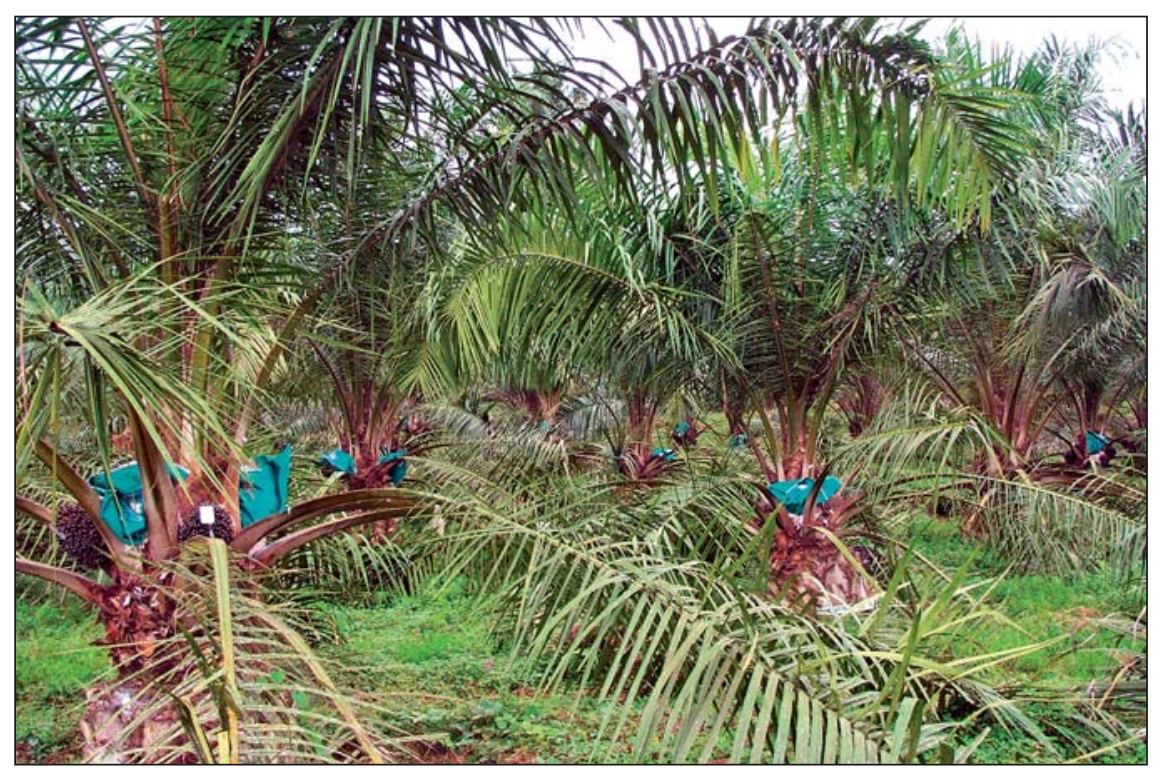

Figure 2. Seed garden in la Mé station (Ivory Cost). Photo : B. Cochard.

The other avenue explored to increase genetic diversity in breeding programmes has been to undertake surveys and set up collections. At the beginning of the 1960s, surveys were carried out in Nigeria [3], followed by Ivory Coast in 1969 [17]. The collection set up at MPOB ${ }^{3}$ is derived from surveys undertaken in numerous African countries: Senegal, Gambia, Sierra Leone, Guinea Conakry, Ghana, Nigeria,

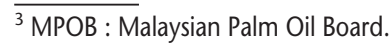

Cameroon, Zaire, Angola, Tanzania and Madagascar [18]. It represents a large share of current oil palm distribution.

The related species Elaeis oleifera, which originates from Latin America, is easily crossed with Elaeis guineensis. It serves as a source of diversity in genetic improvement programmes and has been the subject of numerous surveys [19-21].

Evaluating genetic resources is a lengthy business. The agronomic traits of these populations

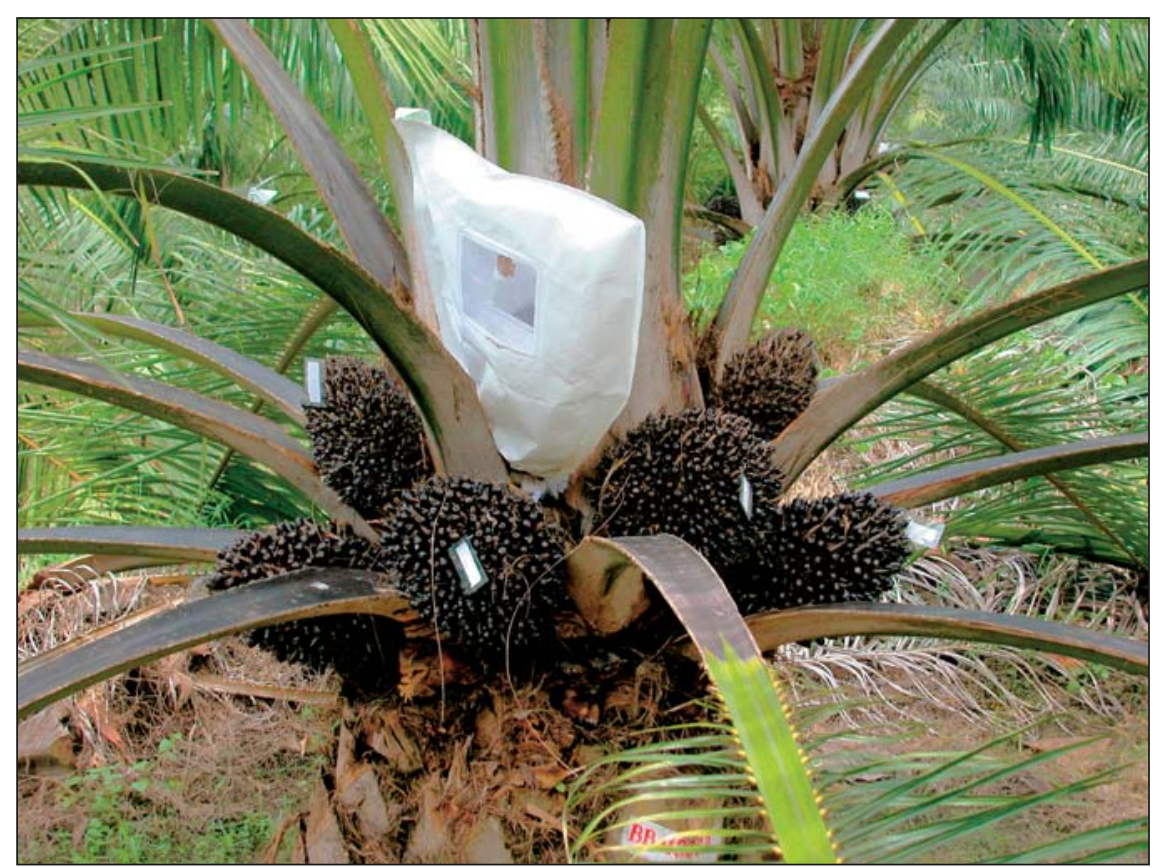

Figure 3. Seed production: female genitor (Photo : T. Durand-Gasselin). often prove to be disappointing. Consequently, specific breeding programmes have to be implemented before it is possible to incorporate this genetic diversity into the selected populations [22]. It has been possible to introduce the best individuals into the recurrent populations [23]. Individuals derived from the Yocoboué populations [24] and an individual from the Angola population [22] have proved worthwhile and have been introduced into the pool of improved parents.

Another strategy developed by MPOB [18] consists in assessing the different surveys on their own merits, and then disseminating the most promising materials to breeders.

\section{Towards a new product}

After discovering substantial heterosis between the palms selected in Asia and those bred in Africa, even greater heterosis was hoped for between $E$. guineensis and E. oleifera. Programmes to create $E$. guineensis $\times$ E. oleifera interspecific hybrids were set up, hoping for very substantial oil gains. Unfortunately, the results fell short of expectations.

The interspecific hybrid trials produced around $55 \%$ less oil than the commercial $E$. guineensis material [25]. Only one E. oleifera population led to an interspecific hybrid that had a production potential of around $70 \%$ that of commercial seeds and the best cross only produced $87 \%$ [25]. Initially, those interspecific hybrids did not have a commercial future. Yet their worthwhile characteristics justified continuing the breeding work. These materials produce an oil that is richer in unsaturated fatty acids (iodine values of 60 to 80 rather than 50 to 60 for $E$. guineensis), have slow vertical growth (20 cm/year rather than 60 for the control) and resistance to diseases (vascular wilt for Africa, and especially bud rot for Latin America). The current objective of breeders is to introgress the qualities of $E$. oleifera into $E$. guineensis through backcross programmes.

However, for the last fifteen years or so, the interspecific hybrid has been unavoidable when replanting certain zones, due to its strong resistance to the bud rot disease existing in Latin America. Consequently, seed production for that type of material now exists. In oil palm estates, yields are sufficient and these hybrids advantageously replace $E$. guineensis which is totally destroyed by bud rot. Work to improve the interspecific hybrid can be undertaken again, not only by studying new origins of $E$. oleifera, but also by exploiting withinprogeny variability; by cloning the best individuals [25]. 


\section{Integrated control of endemic diseases}

The oil palm is susceptible to three more or less specific diseases on each of the 3 continents where it is cultivated. In Africa, vascular wilt, caused by Fusarium oxysporum elaeidis, is rife and can cause up to $70 \%$ mortality [26]. In Southeast Asia, Ganoderma has been known to cause up to $80 \%$ mortality [27]. Lastly, in Latin America, a bud rot disease of unknown origin is rife which causes up to $100 \%$ mortality. For these three cases, genetic control strategies are being developed. We shall only be describing the methods used for the two clearly identified diseases: vascular wilt and Ganoderma.

\section{Improving resistance to vascular wilt}

The symptoms triggered by Fusarium were first described by Wardlaw [28] in the Congo. Thereafter, the disease was observed in numerous plantations in Congo, then Nigeria, Cameroon, Ivory Coast, and throughout West Africa. It is a disease of mature palms when a plantation is set up on former savannah or forest. However, it is a disease of immature oil palms that can occur right from the first year after planting, when replanting is carried out in a zone previously affected by vascular wilt [29]. In the 1960s, chemical control methods were used. They proved to be expensive and ineffectual. At the same time, in plantations, the existence of resistant crosses was discovered. A method was developed to assess the performance of the materials, based on early screening $[30,31]$. By way of this test, it proved possible to define sources of resistance [32] and to define commercial hybrids displaying disease tolerance [33]. This methodology made it possible to substantially reduce the impact of such a disease in an estate such as Dabou in Ivory Coast. In that plantation, 20\% of the palms planted from 1964 to 1967 displayed vascular wilt symptoms, with some crosses at 70\%. From 1976 onwards, following the characterization of resistant crosses, vascular wilt rates decreased considerably and no longer amounted to more than $2 \%$ in 1983 [26]. In the 1990s, the vascular wilt resistance of marketed planting material was further improved, so much so that it is now difficult to find symptoms in plantations.

The improvement of oil palm vascular wilt resistance has made numerous replantings possible in severely infested places. It has thus been possible to maintain this crop in several places, especially in West Africa and, no doubt, that has made it possible to limit further destruction of forests along pioneer fronts. To date, this resistance has proved to be durable, since it has been used for more than 40 years and has yet to be overcome. This is doubtless the result of a selection method that sought polygenic type partial resistances [34]. However, this result has led to a reduction in the genetic diversity of planting material marketed in Africa. The vascular wilt resistance breeding programme is now aiming to diversify the genetic base. As all the populations have sources of resistance [35], it can be hoped that the diversity of the tolerant materials marketed can be improved.

\section{Improving resistance to Ganoderma}

The symptoms associated with this disease were described by Turner [36]. As for vascular wilt, Ganoderma is expressed in mature palms in the first generation, and in immature palms the following generations. Ganoderma mostly exists in Southeast Asia, and a little in central Africa. Mortality can reach $50 \%$ in the most severely affected zones [27]. In addition to dead palms, infected palms that do not display any visible symptoms produce 20 to $40 \%$ lower yields [37].

Studies began with an assessment of different germplasms in plantations. As early as 1971 , differences in performance were found between origins [38] and then confirmed [27]. A performance index in relation to Ganoderma was established from those field observations. It already made it possible to rule out the most susceptible material. In 20-year-old trials, in a context where some of the material displayed $80 \%$ mortality, in some it was only 10 to $20 \%$ [27]. At the present time, an early test is being sought to screen germplasm for Ganoderma, along the lines of the model established for vascular wilt.

\section{New traits to be selected}

Crops are not only extended after clearing primary forests. At the moment, on the three continents, extensions are also being carried out in zones that are less suitable for oil palm growing, i.e. with substantial water deficits or zones that are not appropriate for agriculture. Climatic conditions in Africa have been deteriorating, especially over the last 20 years [39], but oil palm remains an important crop for cultural and economic reasons. For example, in Benin oil palm remains the most productive oil crop [40]. Under these conditions, material adapted to the climatic conditions needs to be created to ensure crop sustainability.

In developed countries, breeders are asked to select planting material that requires less fertilization. Is this feasible for oil palm? In terms of pest control, there are episodic outbreaks in West Africa of a leaf miner (Coelaenomenodera minuta), against which only chemical treatments are effective. Can genetic control of that insect be envisaged?
Lastly, oil palm growing is primarily organized on an agroindustrial scale. However, the smallholder sector is growing in importance. Is there a smallholder specificity that will require breeders to develop special planting material?

\section{Impact of drought}

The impact of drought on oil palm has been widely documented [41-45]. A water deficit strongly affects oil palm growth, the sex ratio, and the rate of aborted female inflorescences, hence yields. Particularly dry spells can kill oil palms, especially when young palms (around 6 years old) are bearing heavy yields.

Agricultural techniques have been developed to lessen the effects of water deficits (for example, by lightening the bunch load in the palms). It proved difficult to implement the techniques and research was undertaken to see whether there existed any genetic traits of resistance to drought. In that way, differences in susceptibility were found between materials [44] though they were not linked to production potential. The best criterion for assessing susceptibility to drought turned out to be the mortality percentage. Substantial differences were identified between and within genetic origins. Some parents seemed simultaneously to display good tolerance and good yields per palm [41]. Other drought tolerance characteristics have been studied. When there is no water deficit, oil palm production is spread over the year. The greater the water deficit, the more pronounced is the production peak. That production peak occurs during the dry period, hence when water requirements are greatest. It would therefore be useful to develop planting material with good seasonable distribution of its yields, despite drought, or with a staggered production peak. Substantial genetic diversity linked to production rhythms has been discovered [46]. However, when water deficits are pronounced, the production cycles of all materials are governed by the same seasonal variations [47].

Lastly, mortality is low in crosses with a high root density [44] and mechanisms of resistance to cell dehydration have been found [48].

These results have usually been obtained in trials not designed for studies of drought tolerance, so they need to be completed by increasing the genetic diversity taken into account, and by designing trials specific to this subject, in order to define one or more selection criteria.

\section{Material with low fertilizer requirements}

Putting it simply, fertilization requirements differ from one continent to the next. Major dominances have been discovered. Potassium is required in Africa and Latin America. In Southeast Asia, it is mostly nitrogen and potas- 
sium that are required. Applications of the other nutrients, phosphorus and magnesium are absolutely necessary on occasions $[49,50]$. Fertilization is currently based on leaf analyses, which have been designed in such a way as to adjust application rates to what is strictly necessary, thereby matching production requirements to socio-economic conditions, whilst remaining eco-friendly. This can no doubt be improved by taking the genotype into account. Indeed, differences in susceptibility have been found between progenies and between clones for different minerals [49-51]. However, it is not known whether those differences express different needs; that remains to be demonstrated.

In the case of oil palm, there are technical constraints to defining fertilizers depending on the germplasm involved. Studying fertilization requirements taking continental specificities into account would mean setting up unrealistic trials. At the moment, given the selection methods used, seeking a fertilization programme adapted to a genotype can only be done using commercially available planting material, running the risk of defining fertilizers adapted to material that is set to become obsolete. Might it not be appropriate to seek methods for the early assessment of nutritional requirements?

\section{Coelaenomenodera minuta control}

This Coleoptera causes major damage episodically in West African oil palm plantations. Differences in susceptibility have been found between origins. Selection criteria need to be defined for setting up genetic improvement programmes based on resistance to this pest. Elaeis oleifera provides such resistance.

\section{Specificity of the smallholder sector}

The oil palm commodity chain is dominated by an agroindustrial sector. The smallholder sector, which was initially supervised by the agroindustrial sector, is also developing considerably outside that influence. Oil palm smallholdings are considered to be sustainable farming models by numerous NGOs [52], which are asking whether the specificity of the smallholder sector can or ought to be taken into account from an agronomic point of view and for planting material selection.

What problems might be specific to the smallholder sector?

For a breeder, what type of specific oil palm should be developed? Palms that are easier to harvest, easier to maintain, higher yielding, requiring few inputs? If these criteria are considered, they clearly concern both sectors. And we have already touched upon these subjects above.
Is it more a problem of access to seeds, in terms of availability, cost, the impossibility of farmers producing their own seeds?

In terms of dissemination, there is not a breeder in every country, and in many countries there are no nurseryman/distributor networks. This encourages the planting of "unselected" oil palms, to the economic detriment of the farmer, but also of the entire commodity chain. Agroindustrialists, on the other hand, have no problem obtaining supplies directly from plant breeders, even if they are on another continent.

In cost terms, seeds amount to 5 to $10 \%$ of the price of a plantation for an agroindustrialist, but 15 to $20 \%$ for a smallholder, since he invests less in fertilizers, infrastructures, etc. Consequently, breeders are often criticized for the high cost of seeds for the smallholder sector. The solution to this problem is political, economic as regards access to credit, but it is not for breeders to risk their own profitability and the quality of the research they have to conduct and fund. It is worth noting that in many countries where the price of seeds produced by the public sector is low, to encourage farmers to buy them, seed quality often suffers. In such cases, everyone is a loser.

Farmers cannot harvest their seeds from their own palms. The differences in yields between this so-called "unselected" material and improved material are such that it would be unfair to recommend such material.

If a farmer intends to formally participate in the oil palm commodity chain, delivering his FFB to a mill, or by producing oil, he has every interest in possessing the same planting material as the agroindustrialists. It is therefore difficult to speak of specificity in the smallholder sector. The main differences would seem to be linked more to agricultural practices, such as promoting intercrops in immature plantings, etc. In Africa, oil palm is a traditional crop. Seeds and unrefined oil, called "red oil", are much appreciated in numerous dishes. For this traditional use of oil palm, it is not essential to have improved material, since it does not necessarily possess the culinary qualities sought. Palms from semi-wild groves can be used. In this case, breeders could easily develop a specific "niche" material which would be more specific to the desired culinary qualities.

\section{Variety dissemination}

The aim of any breeder is to be able to distribute germplasm to farmers that offers new qualities as rapidly as possible.

Several dissemination strategies can be considered. In variety creation programmes, only the best two or three crosses identified could be used. That avenue was not chosen as it would lead to excessive homogeneity in the material marketed, for which there could be vulnerability problems.

To avoid these problems, the planting material marketed needed to be diversified. The crosses chosen to be marketed have been grouped by origin to form "hybrid categories". The current seed production programme being implemented by CIRAD's partners comprises 18 different categories [10]. As far as possible, several unmixed categories are supplied on each delivery.

\section{Conclusion}

Oil palm genetic improvement has always fitted into a sustainable agriculture context. This primarily arises from the perennial nature of this crop, which is intended to last 25 to 30 years, and the plantation even longer if several cropping cycles are undertaken. Consequently, for both smallholders and agroindustrialists, it is necessary to provide certain guarantees when seeds are purchased. Seed purchases can amount to 15 to $20 \%$ of the initial investment in a plantation for a smallholder (not to mention his work time). Plant breeders need to guarantee the quality of their planting material, by guaranteeing its legitimacy (this is a fundamental aspect for oil palm), high yields, resistance to the main diseases (vascular wilt, Ganoderma, bud rot), and be able to advise on the most appropriate material for a given pedoclimatic environment.

Oil palm breeders must continue to improve the yields of this crop, given the continually increasing demand for fats and oils and the substantially reduced possibility of increasing the areas planted to oil palm. They need to pursue genetic control of the different diseases, focusing on durable resistances of a horizontal nature, as is the case for vascular wilt (40 years of proven resistance). Lastly, they must take care to maintain as much genetic diversity as possible, not only in variety creation programmes, but also when distributing commercial seeds.

\section{REFERENCES}

1. LEIPZIG DECLARATION. Global action plan for the preservation and sustainable utilization of plant genetic resources for food and agriculture. FAO. Leipzig. 17-23 June 1996.

2. CALIMAN JP, BERTHAUDA, DUBOS B, TAILLIEZ B. Agronomy, sustainability and good agricultural practices. OCL $2005 ; 2$ : 134-40.

3. CORLEY RHV, TINKER B. The Oil Palm 4th Edition. 2003. Oxford: Blackwell Science LTD: 562.

4. BEIRNAERT A, VANDERWEYEN R. Contribution à l'étude génétique et biométrique des variétés $\mathrm{d}^{\prime}$ Elaeis guineensis Jacquin. Pub Inst Nat Etude agron Congo Belge Ser Sci 1941 ; 27 : 1-101. 
5. GASCON JP, DE BERCHOUX CH. Caractéristiques de la production d'Elaeis guineensis (Jacq.) de diverses origines et leurs croisements. Application à la sélection du palmier à huile. Oléagineux $1964 ; 19$ : 75-84.

6. GASCON IP, JACQUEMARD IC, HOUSSOU M, BOUTIN D, CHAILLARD H, KANGA FONDJO F. La production de semences sélectionnée de palmier à huile Elaeis guineensis. Oléagineux $1981 ; 36: 476-86$.

7. GASCON JP, LE GUEN V, NOUY B, ASMADY KAMGO FONDJO F. Results of second cycle recurrent reciprocal selection trials on oil palm Elaeis guineensis Jacq. Oléagineux 1988; 43 : 1-7.

8. COCHARD B, NOIRET JM, BAUDOUIN L, FLORI A, AMBLARD PH. Second cycle reciprocal recurrent selection in Oil Palm, Elaeis quineensis Jacq. Results of Deli $x$ La Mé hybrids tests. Oléagineux $1993 ; 48$ : 441-51.

9. DAVIDSON L. Management for efficiency, cost effective and productive oil palm plantations. In: Basiron (Ed), Proc 1991 Porim Internationa Palm Oil Conference - Agriculture : 153-67. Palm Oil Res. Inst Malaysia Kuala Lumpur, 1993.

10. DURAND-GASSELIN T, KOUAME KR, COCHARD $B, A D O N B$, AMBLARD P. Diffusion variétale du palmier à huile (Elaeis guineensis Jacq.). OCL $2000 ; 7: 203-6$.

11. HARDON IJ, CORLEY RHV, LEE CH. Breeding and selecting the oil palm. In: AJ Abott, RK Atkin (eds), Improving vegetatively propagated crops. London: Academic Press, 1987: 63-81

12. DURAND-GASSELIN T, DE FRANQUEVILLE $\mathrm{H}$, HAYUN Z, et al. Is it possible and reasonable to produce 10 tonnes of oil per hectare of oil palm? ISOPB, Medan, 6-9 October 2003.

13. COCHARD B, ADON B, KOUAME KR, DURAND-GASSELIN T, AMBLARD PH. Intérêts des semences commerciales améliorées de palmier à huile (Elaeis guineensis Jacq.). OCL 2001 ; $8: 654-8$.

14. $A D J E I A, A D J A D I E$. Diffusion du matériel végétal amélioré de palmier à huile en milieu villageois : l'expérience du Bénin. OCL $2001 ; 8$ : 529-33.

15. DURAND-GASSELIN T, COCHARD B. Oil palm seed distribution. OCL $2005 ; 2$ : 148-53.

16. ROSENQUIST EA, CORLEY RHV, DE GREEF W. Improvement of tenera populations using germplasm from breeding programmes in Cameroon and Zaire. In : Proc of the workshop on progress of oil palm breeding population. Palm oil research Institute of Malaisia, 1990 : 37-69.

17. MEUNIER J. Etude de populations naturelles $\mathrm{d}^{\prime}$ Elaeis guineensis en Côte d'Ivoire. Oléagineux $1969 ; 24: 195-201$.

18. RAJANAIDU N., KUSHAIRI A, RAFII MY, et al. Oil Palm research resources and their utilization- a review. Paper Int Symp Oil Palm genetic resources and utilization. 8-10 June 2000. Malaysian Palm Oil Board, Kuala Lumpur.
19. RAJANAIDU N. Elaeis oleifera Collection en Central and South America. 84-94. Proc Palm Oil Res Inst Malaysia $1986 ; 10: 248$.

20. LE MEUNIER J. Le "palmier à huile" américain Elaeis melanococca. Oléagineux $1975 ;$ 30(2): 51-61.

21. MEUNIER J, AMBLARD P. Prospection E. melanococca Brésil. Rapport préliminaire. IRHO internal document. 1982.

22. ADON B, BAUDOUIN L, DURANDGASSELIN T, KOUAME B. Utilisation de matériel non amélioré pour la sélection du palmier à huile : I'origine Angola. Plant Rech Dév 1998 ; $5: 201-5$.

23. COCHARD B, DURAND-GASSELIN T, ADON B. Oil Palm Genetic Resources in Côte d'Ivoire composition, assessment and use. Int. Symp. "Oil Palm Genetic Resources and utilization". 8-10 June 2000, Malaysian Palm Oil Board, Kuala Lumpur.

24. BAKOUMÉ $C$, ADON B, COCHARD B, POTIER F, DURAND-GASSELIN T, AMBLARD Ph. Assessment of Yocoboué wild oil palm (Elaeis guineensis Jacq.) from Côte d'Ivoire. Euphytica 2001 ; $121: 59-64$.

25. AMBLARD PH, NOIRET JM, KOUAME $B$, POTIER F, ADON B. Performances comparées des hybrides interspécifiques et du matériel commercial E. guineensis. OCL $1995 ; 2$ : 335 40.

26. DE FRANQUEVILLE H, RENARD JL. Improvement of oil palm vascular wilt tolerance. Results and development of the disease at the R. Michaux plantation. Oléagineux 1990; 45 : 399-405.

27. DE FRANQUEVILLE $H$, ASMADY H, JACQUEMARD JC, HAYUN Z, DURAND-GASSELIN T. Indications on sources of oil palm (Elaeis guineensis Jacq.) genetic resistance and susceptibility to Ganoderma sp, the cause of basal stem rot. In: Proc 2001 Int Palm Oil Congr - Agriculture. Malaysian Palm Oil Board, Kuala Lumpur. 2001: 420-31.

28. WARDLAW CW. A wilt disease of the oil palm. Nature $1946 ; 158: 56$.

29. DE FRANQUEVILLE $H$, DIABATE $S$. La fusariose du palmier à huile en Afrique de l'ouest. Plantation Recherche Développement 1995 ; 2(4) : 5-13.

30. PRENDEGAST AG. A method of testing oil palm progenies at the nursery stage for resistance to vascular wilt disease caused by Fusarium oxysporum. Schl I W Afr Inst Oil Palm Res 1963; 4 : 156-75.

31. RENARD JL, GASCON JP, BACHY A. Recherches sur la fusariose du palmier à huile. Oléagineux $1972 ; 27: 581-91$

32. RENARD IL, NOIRET JM, MEUNIER J. Sources et gammes de résistance à la fusariose chez le palmier à huile Elaeis guineensis et Elaeis oleifera. Oléagineux $1980 ; 35$ : 387-93.
33. RENARD IL, MEUNIER J. Research for durable resistance to vascular wilt disease (Fusarium oxysporum $f$. sp. Elaeidis) of oil palm (Elaeis guineensis) in durable resistance in crops. Edited by F Lamberto, JM Waller and NA Van der Graaf. Plenum Publishing Corporation, 1983.

34. MEUNIER J, RENARD JL, QUILLEC G. Heredity of resistance to Fusarium wilt in the oil palm Elaeis guineensis Jacq. Oléagineux 1979; 34 : 555-61.

35. DURAND-GASSELIN T, DE FRANQUEVILLE $H$, DIABATE S, COCHARD B, ADON B. Assessing and utilizing sources of resistance to Fusarium wilt in oil palm (Elaeis guineensis Jacq) genetic resource. Int Symp "Oil palm genetic resources and utilization". 8-10 June 2000, Malaysian Palm Oil Board, Kuala Lumpur.

36. TURNER PD. Infection of oil palms by Ganoderma in Malaya. Oléagineux 1966; 21 : 73-6.

37. KHAIRUDIN H. Basal stem rot of oil palm caused by Ganoderma boninse - an update. In: BS Jalani et al. (eds), Proc 1993 PORIM Int Palm Oil Congr - Agriculture. Palm oil Res. Inst. Malaysia. Kuala Lumpur. 1995 : 739-49.

38. AKBARU, KUSNADI M, OLLAGNIERM. Influence de la nature du matériel végétal et de la nutrition minérale sur la pourriture sèche $d u$ tronc du palmier à huile due au Ganoderma. Oléagineux $1971 ; 26: 527-34$.

39. RAPPORT D'ACTIVITÉ IRHO-CIRAD. Oléagineux $1992 ; 47: 297-8$.

40. DJEGUI N, DANIEL C. Le développement du palmier à huile au Bénin : une approche spécifique. OCL $1996 ; 3: 125-30$.

41. NOUY B, BAUDOUIN L, DJEGUI N, OMORE A. Le palmier à huile en conditions hydriques limitante. Plantation Recherche Développement $1999 ; 6: 31-45$.

42. CORLEY RHV. Inflorescence abortion and sex differentiation. In: RHV Corley, IJ Hardon, BJ Wood (eds), Oil Palm Research. Amsterdam: Elsevier Scientific Publishing Company, 1976.

43. HARTLEY CWS. The Oil Palm. 3rd Edition. London : Longman, 1988.

44. HOUSSOU M. Amélioration du palmier à huile (Elaeis guineensis Jacq.) en zone peu humide. Résultats récents obtenus au Bénin. Thèse Université Paris Sud Orsay. France, 1985.

45. MAILLARD G, DANIEL C, OCHS R. Analyse des effets de la sécheresse sur le palmier à huile. Oléagineux $1974 ; 29$ : 8-9.

46. NOUY B, OMORE A, POTIER F. Oil palm production cycles in different ecologies: consequences for breeding. In : PORIM International Palm Oil congress. 1996: 62-75. 
47. CORLEY RHV. Oil Palm yield components and yields cycles. In : DA Earp, W Newall ed, Oil palm. Kuala Lumpur. Incorp. Soc Of planters, Malaysia : 116-29.

48. CORNAIRE B, DANIEL C, ZUILY-FODIL Y, LAMADE E. Le comportement du palmier sous stress hydrique. Données du problème, premiers résultats et voies de recherche. Oléagineux $1994 ; 49: 1-12$.
49. CALIMAN JP, DANIEL C, TAILLIEZ B. Oil palm mineral nutrition. Plantation Recherche Développement $1994 ; 1: 36-54$

50. JACQUEMARD J CH, TAILLIEZ B, DADANG K, OUVRIER M, ASMADY H. Oil palm (Elaeis guineensis Jacq.) nutrition: Planting Material effect. In: 2002 International Oil Palm Conference. 8-12 July 2002. Nusa Dua, Bali, Indonesia.
51. DUBOS B, CALIMAN JP, CORRADO F, QUENCEZ P, SISWO SUYANTO, TAILLIEZ B. Importance of magnesium nutrition in oil palm. Plantation Recherche Développement $1999 ; 6: 313-25$.

52. RSPO Factsheet. Round Table on Sustainable Palm Oil. November 2004. www.sustainablepalmoil.org. 